enorden

\title{
7 NORDIC STORIES
}




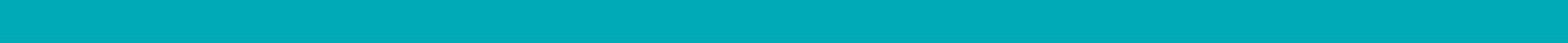




\section{NORDIC STORIES}

FOREWORD 
ISBN: 978-92-893-2494-6

http://dx.doi.org/10.6027/ANP2013-723

ANP 2013:724

(C) Nordic Council of Ministers

Editor: Bodil Tingsby

Contributors: Anita Skoglund, Jesper Schou-Knudsen, Bodil Tingsby,

Heidi Orava, Louise Hagemann, Karin Arvidsson, Michael Funch.

Translation: Tam McTurk

Layout: Jette Koefoed/Nordic Council of Ministers

Photos:

Cover: Jette Koefoed/norden.org

P. 6-8: Benjamin Suomela/norden.org

P. 11-12: ImageSelect

P. 13: Karin Beate Nøsterud; Johan Wessman/norden.org

P. 14-17: ImageSelect; www.nordic built.org

P. 18-21: Johannes Jansson/norden.org; ImageSelect

P. 22-23: Johannes Jansson/norden.org

P. 25-27: Vita Thomsen/norden.org; Ane Cecilie Blichfeldt /norden.org;

Johannes Jansson/norden.org

Print: Rosendahls Schultz Grafisk

Copies: 700

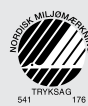

Printed in Denmark

\section{Nordic Council of Ministers}

Ved Stranden 18

DK-1061 Copenhagen $\mathrm{K}$

Telephone (+45) 33960200

\section{Nordic Council}

Ved Stranden 18

DK-1061 Copenhagen $\mathrm{K}$

Telephone (+45) 33960400

\section{Nordic co-operation}

Nordic co-operation is one of the world's most extensive forms of regional collaboration, involving Denmark, Finland, Iceland, Norway, Sweden, and Faroe Islands, Greenland, and Åland.

Nordic co-operation has firm traditions in politics, the economy, and culture. It plays an important role in European and international collaboration, and aims at creating a strong Nordic community in a strong Europe.

Nordic co-operation seeks to safeguard Nordic and regional interests and principles in the global community. Common Nordic values help the region solidify its position as one of the world's most innovative and competitive. 


\section{FOREWORD}

Seven Stories consists of snapshots of official Nordic co-operation in 2012 - just seven out of thousands of stories, but ones that highlight the depth, breadth, staying power and importance of co-operation for each and every one of us in the Nordic Region.

Sometimes, official co-operation affects people clearly and directly, like when the Nordic Council decided in 2012 to allow open access to its committees. The enthusiastic Danes in the Nordic Fashion Association were quick to seize the opportunity and seek help with their plans for sustainable fashion. Within months, the imposing Finnish Parliament was providing the setting for a packed catwalk show during the Session in Helsinki in October.

The many media reports about people adversely affected by seemingly unnecessary barriers to mobility between the Nordic countries were a clear reflection of the importance of the ongoing discussions about freedom of movement, which led to a series of debates on the issue in all of the Nordic parliaments in April.

On one bitterly cold day in February, an entire industry convened to engage in a discussion initiated by the Council of Ministers about the feasibility of new standards for sustainable con-

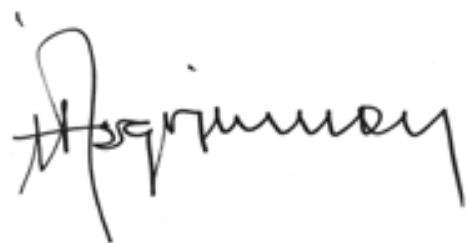

Hálldor Āsgrímsson

Secretary General

Nordic Council of Ministers struction. Top executives from a hundred companies are already signed up and fully committed to making sustainability a tool for enhancing competitiveness.

Sometimes, the distance from start to finish seems much greater - like when the decision was finally taken to launch the Nordic Children's Literature Prize. Or when Sweden and Finland announced at the Session that they will help Norway with air surveillance over Iceland, a tangible sign of the ever-closer Nordic co-operation on foreign, defence and security policy, an issue that has been discussed since the 19th century.

Difficult issues take time. For example, the welfare state's ability to be inclusive of individuals whose background and life circumstances do not fall within expected norms. The culture ministers made sure this was a hot topic and generated much debate at the Gothenburg Book Fair, the largest book fair in the Region.

For those who think that not much goes on in the Nordic Region, we highly recommend a look at the Nordic Statistical Yearbook, which celebrated its 50th anniversary in 2012. Seven Stories reflects on a unique and surprising half-century.

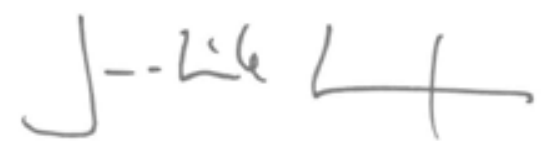

Jan-Erik Enestam

Secretary General

Nordic Council 


\section{7}

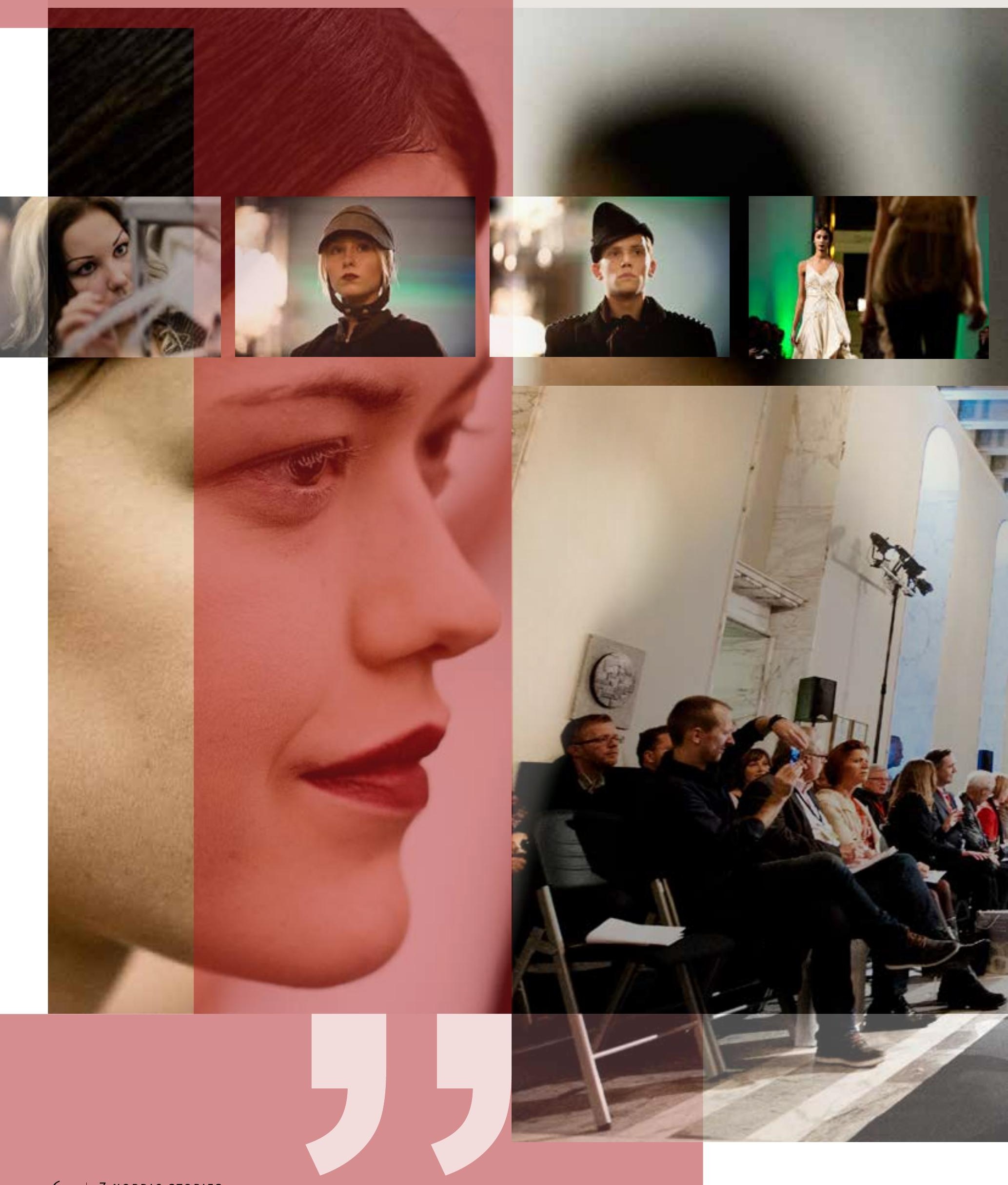




\section{THE CATWALK \\ - a new arena for Nordic sustainability policy}

BY HEIDI ORAVA

THE ACCESSORIES ARE ALL LAID OUT AND WAITING. JUST ONE FINAL BLAST OF HAIRSPRAY, AND THE MODELS WILL BE READY TO HIT THE CATWALK IN THE FINNISH PARLIAMENT. ALL OF THEM ARE WEARING CREATIONS THAT MAKE A POINT - SOME ARE MADE OF NEW MATERIALS PRODUCED USING SUSTAINABLE METHODS, OTHERS OF RECYCLED FABRICS THAT COMPROMISE ON NEITHER STYLE NOR QUALITY. NORDIC SUSTAINABILITY POLICY HAS MADE INROADS INTO A WHOLE NEW ARENA.

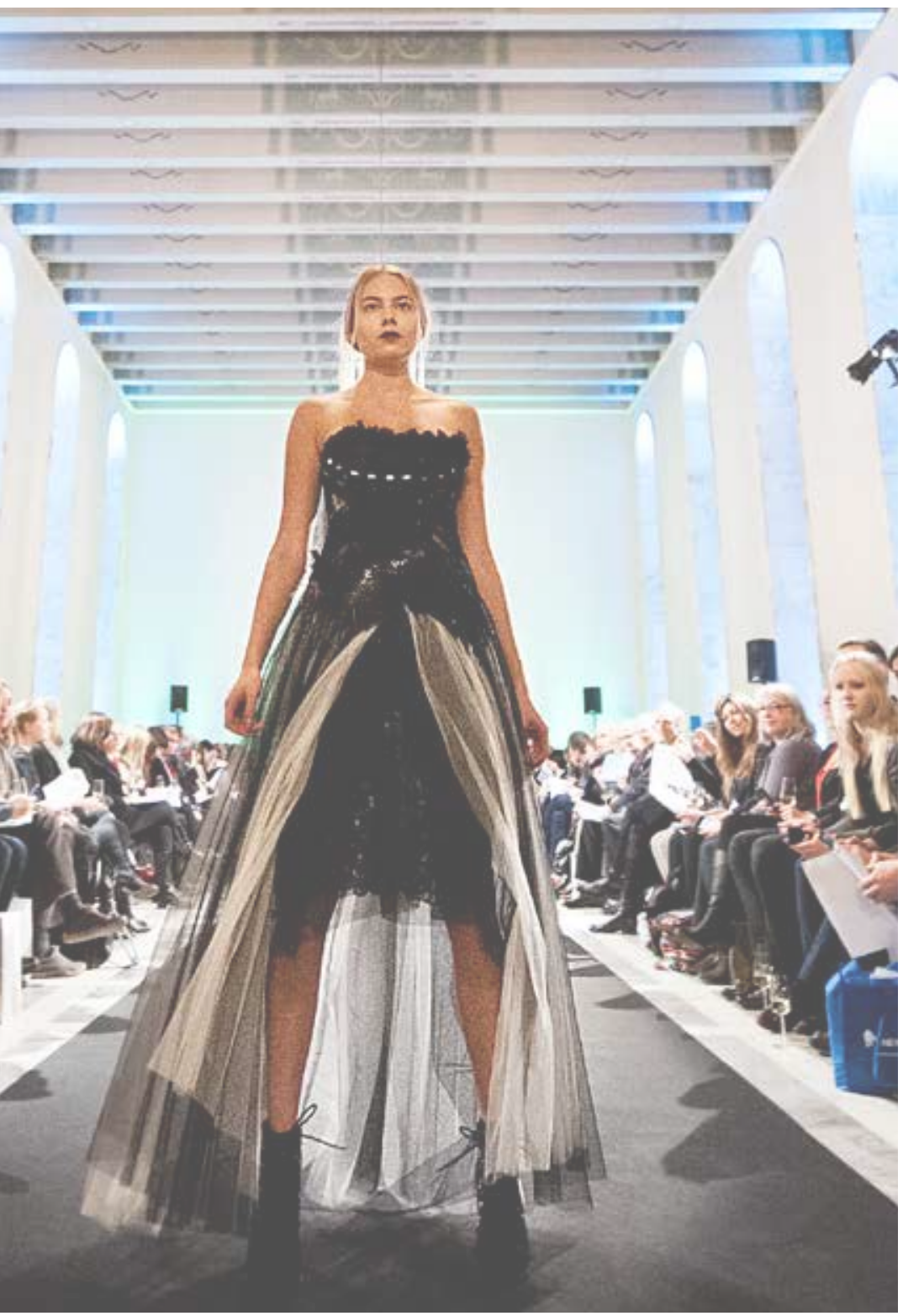

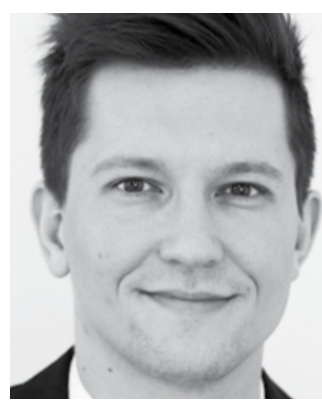

JOHAN ARNø KRYGER

Project Co-ordinator

Nordic Fashion Association

(NFA)

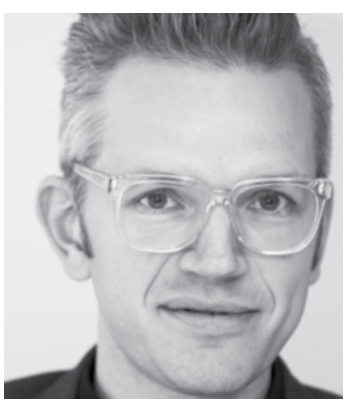

JONAS EDER-HANSEN

Development Director

Nordic Fashion Association (NFA)
$\mathrm{I}$ $\mathrm{n}$ the audience sit politicians, journalists and officials. Some appear a little unsettled by the usually formal chamber's new look - is this not a bit frivolous? But their reservations will quickly be set aside. Each garment that swishes past represents a living manifestation of the sustainability policy so strongly advocated by politicians from the whole of the Nordic Region.

"If any industry can change the world, it's the fashion industry. It shapes how we think of each other and our culture, so has huge potential as a means of conveying messages that go way beyond the values with which the industry is traditionally associated - sustainability is a 


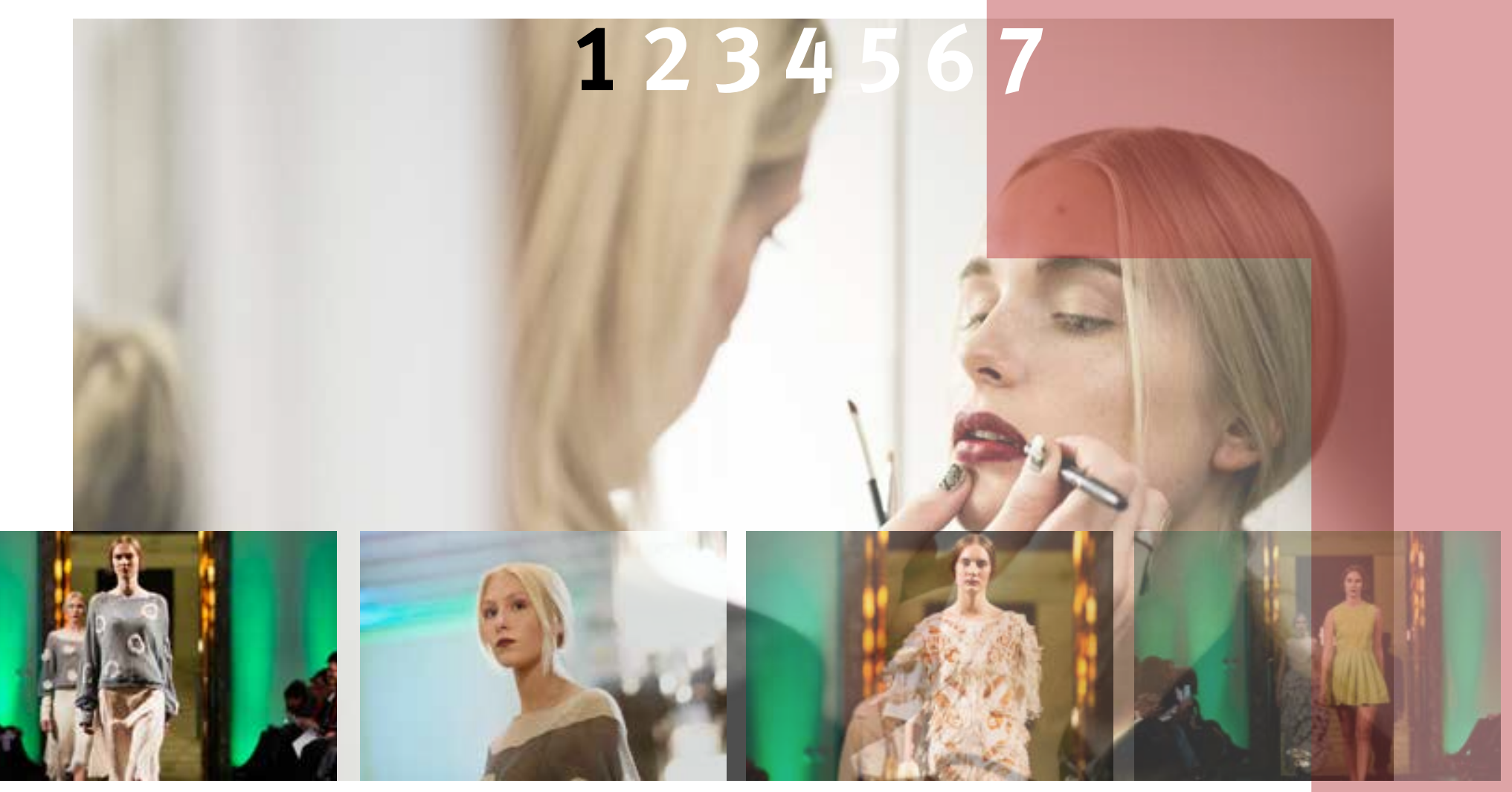

prime example," says Jonas Eder-Hansen, Development Director of the Danish Fashion Institute. Since 2008, he has been one of the driving forces in bringing together people who work with sustainable fashion, culminating in the establishment of the Nordic Fashion Association (NFA).

\section{CITIZENS' INITIATIVE MAKES ITS MARK}

The catwalk show in the Finnish Parliament was held as part of the Session of the Nordic Council in 2012, but the idea originally arose out of a citizens' initiative. Since early 2012, citizens and organisations in the Region have had the right of open access to Nordic Council committees, and the NFA was one of the first to seize the opportunity and put forward its views.

"The dialogue with the Nordic Council has been very positive," says Johan Arnø Kryger, project co-ordinator at the NFA. "Much of it focuses on finding business models that make sustainable design profitable, even for small and medium-sized enterprises. It also has to result in good design, of course, so in this way we are also making a contribution to a growing industry."

The potential for growth in sustainable fashion is made starkly visible when Kryger holds up a knitted black-and-white tunic. The garment is made from a blend of wool and milk protein, with a soft, silky neckline of milk protein. The high prices and the production footprint associated with cotton have stimulated the development of textiles that are environmentally friendly, inexpensive to produce and completely recyclable.

Recycling of textiles was also included in one of the projects that laid the foundation for the Nordic prime ministers' 2011 initiative The Nordic Region - leading in green growth. Eder-Hansen refers to the studies commissioned by the Nordic Waste Group to find new techniques and methods of textile processing.

"The potential for recycling textiles is fantastic," says Eder-Hansen. "Improving our ability to reuse fibres in clothing will reduce the amount of textile waste."

"In the Nordic Region, we have a culture of taking care of each other and our surroundings," says Kryger. "We also have a design tradition that is compatible with this agenda. Consumers brook no compromise when it comes to quality, price or design. We have to create fashion based on these sustainable considerations, and the good news is that it can be done."

\section{ECO-LABELLING ISN'T JUST FOR FOOD}

One of the challenges in establishing a more sustainable fashion industry is to make the consumers aware of the consequences of their purchasing decisions. One way of doing so is to better utilise 
the small label that currently carries washing instructions - something that the NFA is negotiating with companies in the industry.

Industry professionals need knowledge and information too. One of the NFA's early initiatives was to draw up a set of sustainability rules for small and medium-sized fashion companies to refer to when contracting suppliers abroad. These were presented at the Copenhagen Fashion Summit, which ran in parallel with the COP15 summit in Copenhagen in 2009.

"Right now, the Nordic Region has momentum in fashion and design, and we must not let the initiative slip from our grasp," says Kryger. “Consumers in Beijing and New York aren't just buying clothes, they're also buying into the story of the Nordic Region - a story of simplicity, purity and durability. We have a niche that affords profiling opportunities for the whole Region - and the growth opportunities are endless."
The Nordic Council's meeting with the Nordic Fashion Association resulted in a committee proposal, called New Nordic Fashion, which the Business Committee presented to the Session of the Nordic Council. The proposal was approved in plenary and submitted in the form of a recommendation to the Nordic Council of Ministers (see the fact box).

\section{FACTS}

Four facts about your clothes

- The fashion and textile industry is the world's thirdlargest industry and has an annual turnover of DKK 2,770 billion (approx. $€ 370$ billion)

- $\quad$ Producing a T-shirt uses about 2,500 litres of water in the process from cotton seed to shop shelf. A pair of jeans consumes 3,500 litres.

- The industry can have a positive effect on the emission of greenhouse gases by selecting materials carefully. Durable textiles can be made of things like bamboo, nettles, seaweed, shellfish shells and corn.

- In the Nordic Region, we throw out 10-25 kg of clothing and textiles per person per year. On average, $80 \%$ of the discarded clothes have $75 \%$ of their useful life left.
The Nordic Council submitted a recommendation to the Council of Ministers following its Session in Helsinki. Its proposals are:

- to develop and start up a joint Nordic in-service training for designers, business developers, buyers, communicators and shop assistants

- to start up a co-ordinated effort for a joint Nordic recycling programme for clothes and textile goods

- $\quad$ to develop joint export initiatives and new business models for New Nordic Fashion in a "Green Growth" perspective. 


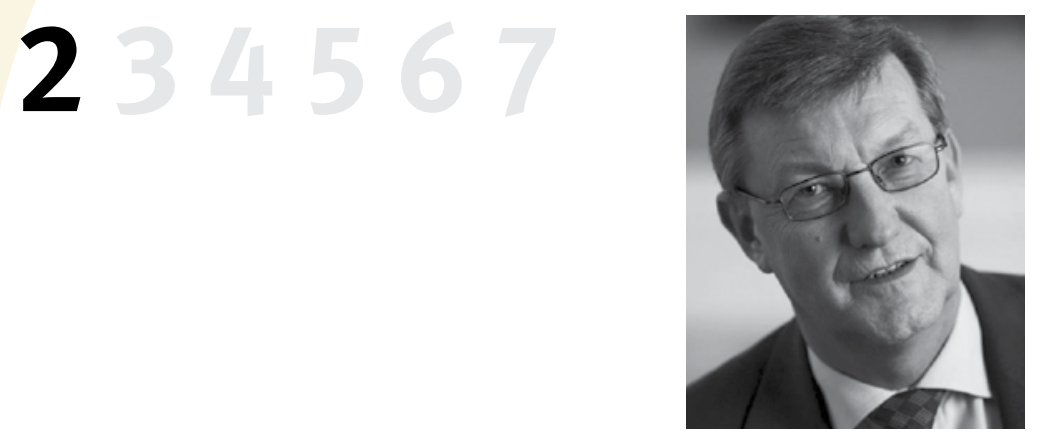

\section{Debate on FREEDOM of movement provides a new Nordic platform}

BY ANITA SKOGLUND

IN APRIL 2012, DEBATES ON FREEDOM OF MOVEMENT IN THE NORDIC REGION WERE HELD IN ALL THE NORDIC PARLIAMENTS FOR THE FIRST TIME. OLE STAVAD, A MEMBER OF THE FREEDOM OF MOVEMENT FORUM, IS DELIGHTED WITH THE INITIATIVE AND PLEASED WITH THE OUTCOME OF THE DANISH DEBATE:

“I THINK THIS IS THE FIRST TIME IN THE MANY YEARS THAT I'VE BEEN INVOLVED THAT THE NORDIC AGENDA AND FREEDOM OF MOVEMENT HAVE BEEN SO HIGHLY PRIORITISED BY THE GOVERNMENT. NORDIC AFFAIRS HAVE A WHOLE NEW PLATFORM IN DENMARK.”

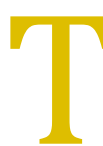
he proposal to hold the theme debates was raised just a few months earlier, at a joint meeting of the Nordic Council Presidium and the Freedom of Movement Forum. One of those who attended the meeting was Ole Stavad, a former Danish tax and industry minister and current member of the Freedom of Movement Forum. Stavad welcomes the debates and the continuing interest in the issue in the Danish parliament and government.

Ahead of the debate, the Danish government and delegation to the Nordic Council met to discuss how it should be organised and summed up. The government submitted a report to Parliament outlining a number of specific topical issues.
These formed the basis for the debate and became part of the ongoing work to remove obstacles to cross-border freedom of movement.

During the debate, Parliament called on the government to invite the parties represented in the chamber to negotiate a binding agreement on the work to remove barriers that hinder the free movement of people and companies in the Nordic Region. Parliament adopted the proposal unanimously.

This decision kick-started a process in both government and Parliament, and several meetings have since been held to discuss an actual agreement. Stavad hopes it will be reached in early 2013. He thinks that the current talks represent 


\section{7}

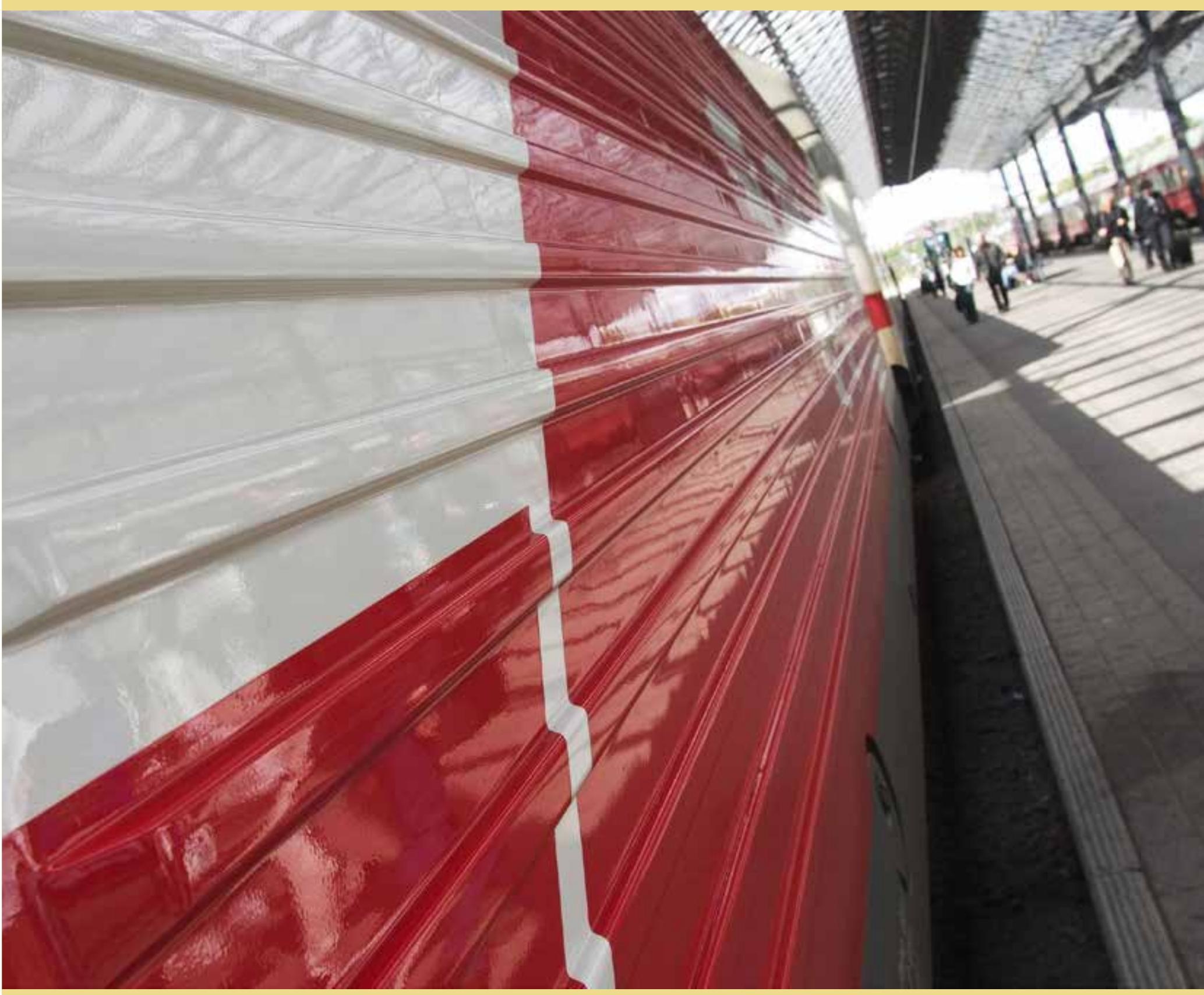




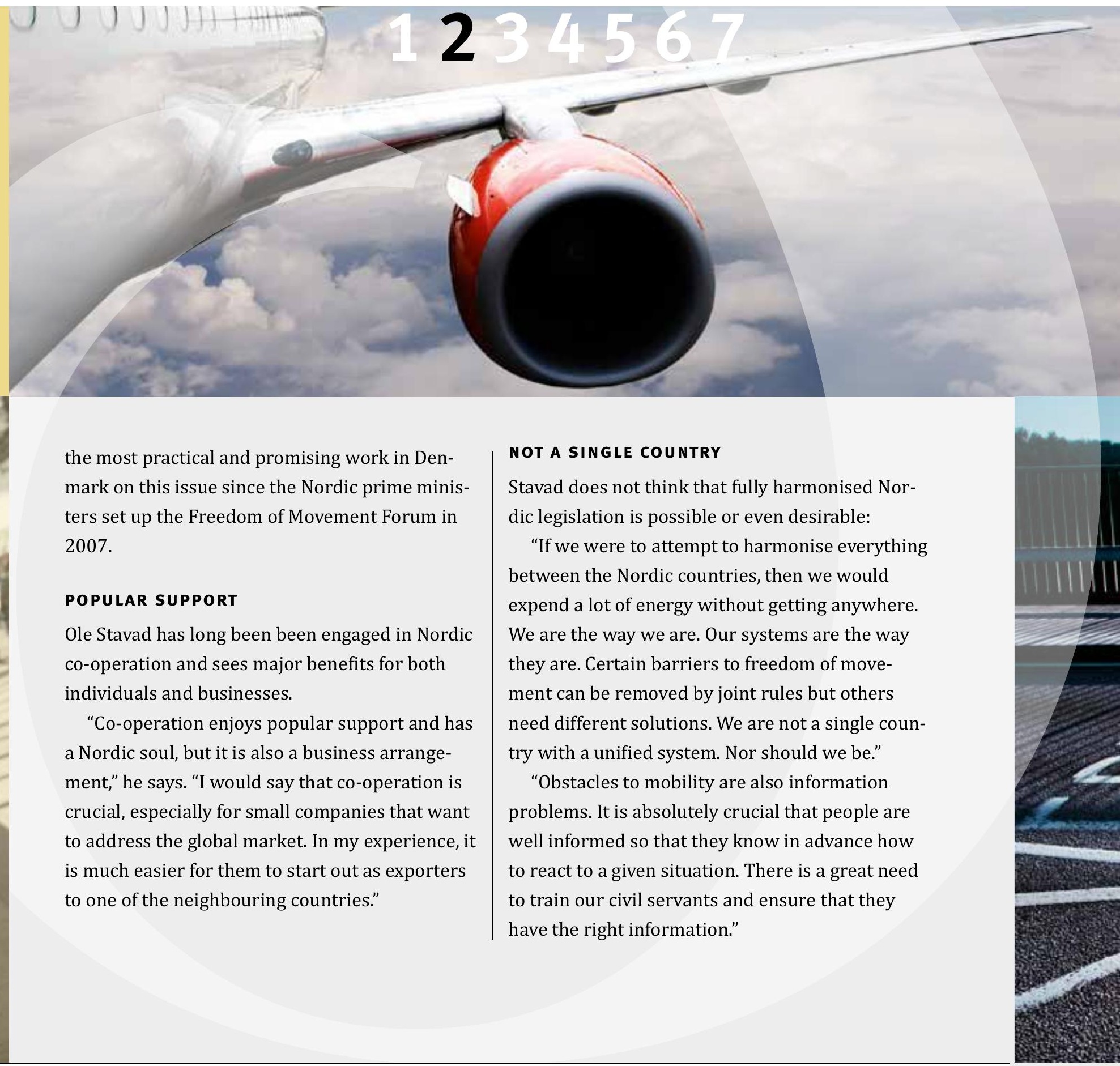

\section{Obstacles to cross-border freedom of movement}

The work to remove barriers to mobility aims to create a more open Region. It should be easy to live or work in another Nordic country. No one should be at risk of falling through the cracks or be hindered by unclear laws and regulations in the tax and social security systems. However, in most areas of society, obstacles to freedom of movement exist that complicate the lives of thousands of people in the Region and impact on labour and business mobility. In April 2012, theme debates on freedom of movement were held in all of the Nordic parliaments.

\section{Freedom of Movement Forum}

The Freedom of Movement Forum is a politically appointed body commissioned by the Nordic governments to promote freedom of movement in the Region for individuals and businesses. Its remit is, in dialogue with the national governments, to identify, prioritise and propose solutions to real-life obstacles to cross-border mobility between the countries. The forum consists of one representative from each of the Nordic countries, including Åland. 


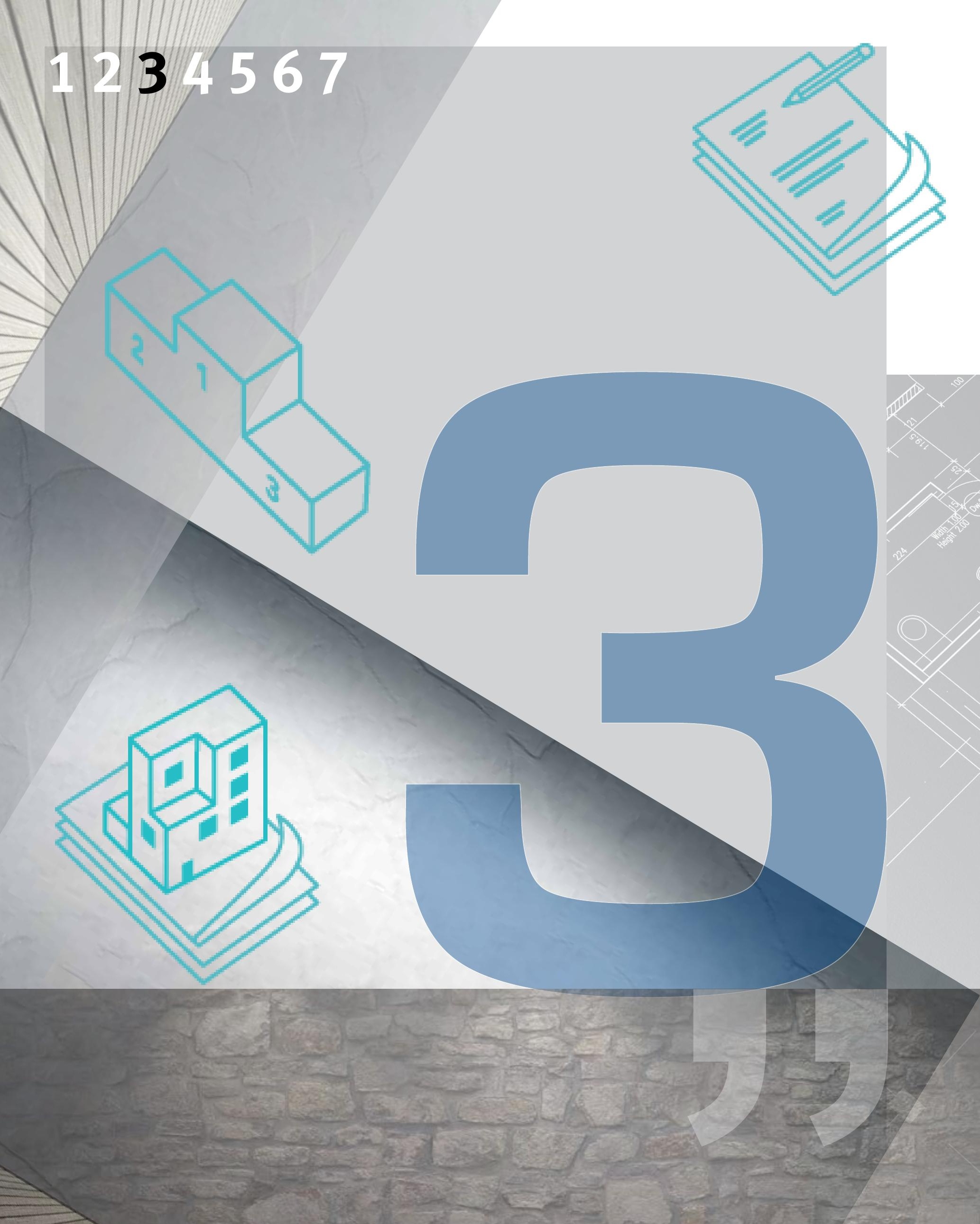

1234567 


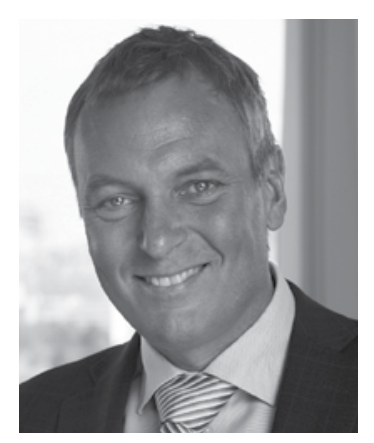

IT PAYS. AND IT'S GOOD FOR THE ENVIRONMENT AND FOR HUMAN HEALTH. THE NORDIC BUILT CHARTER SETS NEW STANDARDS FOR SUSTAINABLE BUILDING AND MOVES THE CONSTRUCTION INDUSTRY FORWARD, BOTH AT HOME AND ABROAD. HOWEVER, POLITICIANS AND REGULATORY FRAMEWORKS STILL LAG SOME WAYBEHIND, ACCORDING TO LEADING LIGHTS IN THE NORDIC CONSTRUCTION INDUSTRY.

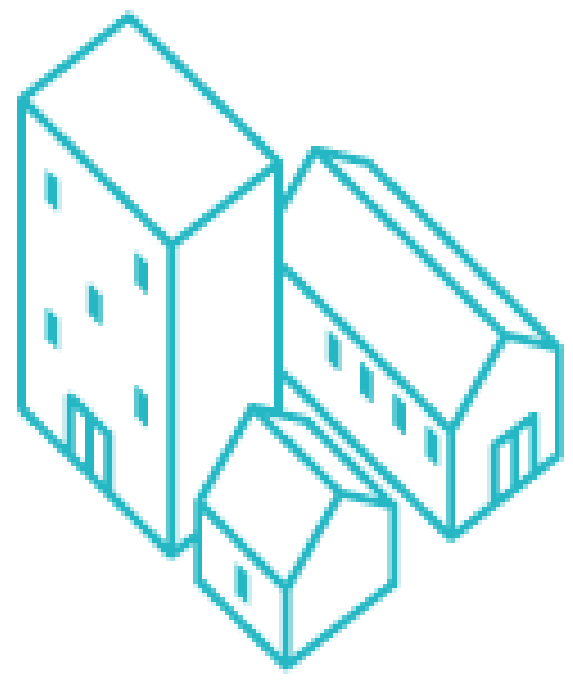

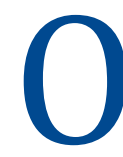
$n$ a bitingly cold February day in 2012, 65 top officials from the Nordic construction industry gathered at Schæffergården in Copenhagen to discuss sustainable building. They did so at the behest of the Nordic Council of Ministers, as part of the countries' joint efforts to meet the many challenges posed by globalisation.

The task was to come up with ideas for how the Nordic Region can contribute to more climate-friendly building solutions while enhancing the national economies. The answer was the Nordic Built Charter, a set of principles that focuses on the needs of both people and the environment. 
Nordic Innovation, an institution under the Council of Ministers, took up the baton and by the end of 2012 more than 100 companies - from architects and manufacturers to contractors - had already signed the charter. Local authorities and other public-sector agencies have expressed their support and a number of leading lights in the industry have signed up as ambassadors for the project.

\section{DEMAND}

One of the ambassadors is Director Rolf Thorsen of NCC Property Development in Norway, who sees no contradiction between market forces and sustainability. On the contrary - the market now demands sustainable solutions. In his opinion, it is actually the politicians and legislation that are lagging behind.

"The public sector is the biggest developer and leaseholder in the Region," he says. "But politicians tend to only look at the short term when they make investments. It costs more to build sustainably. But you claw it back in the form of lower operating costs and a better working environment for the people who use the buildings."

Studies show that workplaces built with respect for people and the environment provide greater job satisfaction, and this ultimately has a positive effect on the bottom line. Other economic benefits can also be reaped, especially at a time of rising energy prices.

\section{SINGLE NORDIC MARKET}

On the question of why we must co-operate on this at Nordic level, Thorsen is clear:

"If we work together to draw up common standards and technical requirements across the Nordic countries, suddenly we have a much larger home market. This keeps costs down and boosts profitability for the individual company. The biggest Nordic construction companies already have offices in all of the neighbouring countries, but this new form of co-operation can also make a big difference to the small players."

For example, a commonly cited calculation shows that simply co-ordinating the requirement for the height of steps across the five Nordic countries would save huge amounts of money and open new cross-border markets for a number of companies. The public sector has a crucial role to play here by demanding not only more consistent but also more sustainable standards.

\section{ATTITUDES AND VALUES}

The Nordic Council of Ministers, at the request of the prime ministers, has launched a number

\section{Nordic Built Charter:}

"We will create a built environment that:

- Is made for people and promotes quality of life

- Pushes the limits of sustainable performance, as a result of our innovative mind-set and high level of knowledge

- Merges urban living with the qualities of nature

- Achieves zero emissions over its life cycle

- Is functional, smart and aesthetically appealing, building on the best of the Nordic design tradition
- Is robust, durable, flexible and timeless - built to last

- Utilises local resources and is adapted to local conditions

- Is produced and maintained through partnerships founded on transparent collaboration across borders and disciplines

- Employs concepts that are scalable and used globally

- Profits people, businesses and the environment" 
of green-growth initiatives, one of which looks precisely at the possibility of introducing uniform technical standards and norms in construction. This will generate economic growth and jobs especially if the Region is used as a springboard to the larger global market.

But the Nordic Built Charter goes further. It's also about attitudes.

"The construction industry in the Nordic countries is in many ways at the forefront as regards sustainability," says Thorsen. "Firstly, we face significant challenges because of our climate. But we also have a culture and a set of values that mean that we can take the lead in this area. And if we can be a leader in technical solutions, we can also be a leader in terms of attitudes."

At the UN Sustainability Conference in Rio, it emerged that the business community is to a great extent pushing to find new, sustainable ways of operating. According to Thorsen, when working on innovative solutions that transcend borders, it is an advantage that the Nordic countries have a great deal in common.

\section{MOTIVATIONAL AND FUN}

NCC is building new headquarters in Oslo. It is to be a so-called "passive house" that does not use more energy than it generates. The staff of the
NCC are enthused by the prospect of the Nordic Built Charter.

"Our staff are really taking up the challenge, and we are in the process of developing new IT solutions that will underpin the Charter. We are, for example, developing new 3D projections that support the development of sustainable building and the new demands we have placed on ourselves," says Rolf Thorsen.

He is convinced that, in the long term, it is the right thing to do economically. The requirement for sustainability drives both technological and business development. "And it's fun too," concludes the director of one of the Region's many forward-thinking companies, who would very much like to see ambitious policies on which to build for the future.

\section{FACTS}

\section{Nordic Built Challenge:}

The Nordic Built Challenge is a competition for the sustainable renovation of five buildings based on the principles contained in the Nordic Built Charter. Renovation of existing building stock is considered the fastest way to more climate-friendly construction.

For more details, see www.nordicbuilt.org

\section{Nordic Built Ambassadors:}

COWI, the Danish Energy Agency, Henning Larsen Architects, $K A B$, Velux, Batteríið, EFLA Consulting Engineers, Government Construction Contracting Agency in Iceland, Iceland Green Building Council, Entra Eiendom, NCC Property Development, Snøhetta, Zero, ByggVesta, SINTEF Byggforsk, Pöyry, Uponor and Skanska. 
1.34

4567 


\section{4}

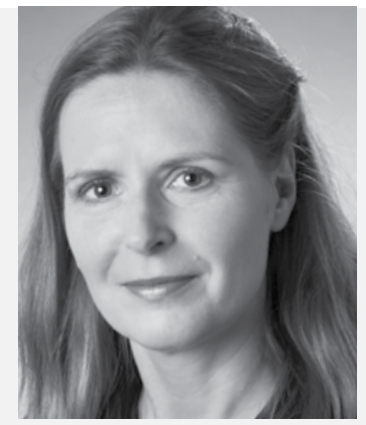

\section{Seal of approval for CHILDREN'S literature}

BY JESPER SCHOU-KNUDSEN

PREVIOUS ATTEMPTS - BY MINISTERS, MPS, WRITERS, SCHOLARS, AND ORDINARY READERS - HAD COME TO NOTHING. BUT ON 31 OCTOBER 2012, THE TIME WAS RIGHT. THE SESSION OF THE NORDIC COUNCIL ADOPTED THE CULTURE MINISTERS' PROPOSAL TO CREATE A BRAND-NEW PRIZE: THE NORDIC COUNCIL CHILDREN'S AND YOUNG PEOPLE'S LITERATURE PRIZE. IT RESONATED, NOT ONLY IN TERMS OF CULTURAL POLICY BUT THROUGHOUT A REGION RENOWNED FOR ITS LOVE OF CHILDREN'S LITERATURE.

$\mathrm{T}$ his is not something that happens every day. The Nordic Council is very choosy about its prizes. There are only four of them, and they are highly prestigious and a source of great pride - especially the Literature Prize, which for half a century has extolled the virtues of authors, helped circulation explode and caused the media to go into overdrive. Now there is a fifth.

But what is the point of the prize - what can it do? Is it more than just an long-overdue sprinkling of stardust upon a literary genre under pressure, one which some claim is mired in Nordic, national-romantic nostalgia with a dash of Pippi
Longstocking, the Moomins and Rubber Tarzan? Associate Professor Nina Christensen, Head of the Centre for Children's Literature at Aarhus University in Denmark, has no doubts about why it is important to give the genre the recognition that comes along with the prize:

"As far as recognition is concerned, I think it's quite simple. Society should recognise and highlight the very best performances in a given field. In this case, the field is the texts young people encounter while they are developing their own language. So I'm more surprised that there wasn't a prize before now than I am that one has been set up." 
When the culture ministers and the Nordic Council recently decided to create a prize for Nordic children's and young people's literature, they highlighted Pippi Longstocking, the Moomins and Karius and Baktus as the brightest beacons in the genre. But is this really the best we can do?

"When people are asked to cite titles, they often revert to older literature," says Christensen. "This is almost certainly due to the fact that new titles have to contend with the fact that we typically read children's literature at three particular times in life: as kids, as parents and as grandparents. The gaps can be as long as 20-30 years, during which - as adults, and for good reasons - we don't really follow trends unless we work with children and literature."

"This can make it difficult for new and perhaps more experimental literature to find space on the bookshelf at home. On the other hand, it thrives in schools and libraries, so when children leave school they will typically have a more up-to-date picture of current children's literature than their parents," she points out.

Outside the Region, the broad political support for Nordic art and culture causes something of a stir. But is it really a political task to run a prize that supports and promotes a specific - some would say marginal - literary genre?

"Children are citizens too. And hardly a marginal group," says Christensen. "They spend a lot of time reading, both at home and in schools and daycare, and plenty of Nordic children's books are published every year. So from a market-, institution- or user-perspective, children's literature is not marginal. But it is largely invisible in the me- dia, and hopefully a prize will help to change that."

The decision on 31 October to establish a new Nordic prize was unanimous, and politicians queued up to stress what is unique about Nordic children's and young people's literature. But is there a specific Nordic tradition in children's literature? And if so, what differentiates it from that of other countries?

"Most children in the Nordic Region will have encountered the likes of Astrid Lindgren, Hans Christian Andersen, Tove Jansson and Thorbjørn Egner," says Nina Christensen. "A great deal of their work is translated into the other Nordic languages, so it is reasonable to say that in both a historical and a contemporary perspective there is indeed a Nordic tradition. What is special about Nordic children's literature is partly that new literature can draw on this tradition - that the legacy of older literature echoes through the new texts."

"But equally important is that the Nordic countries have a tradition that the child is an independent individual who needs to be challenged. Compared to other countries, there are fewer taboos in Nordic literature, and sometimes the humour and irony are a little sharper. These are certainly the kind of reactions I encounter when I and my colleagues discuss Nordic literature in international contexts," she says.

When the seal of approval was extended to children's literature last autumn, the politicians also agreed that it would simultaneously constitute a bulwark against external mass culture, even though Facebook, computer games and YouTube have long since found their way into children's 
bedrooms in the Region, supplanting the book as the preferred media for developing minds.

But what about my own daughter, who at six is more fond of computer games from the USA and fairy tales by the Brothers Grimm than of stories by modern Danish children's authors? Does she just have bad taste or are the alternatives not sufficiently visible? Will a new prize help to curb commercial (especially American) mass culture?

"Children today have access to so many forms of narrative, and often there's an interaction between, e.g. books, films and computer games," says Nina Christensen. "There's such a big difference between the Brothers Grimm and the linguistic universe your daughter meets in a computer game. For me, it suggests that children are also inquisitive individuals who have a strong appetite for many different things. What is important is that children have access to a range of different forms of expression so that they are able to find and develop their own taste."

She emphasises, however, that this will not be done by awarding a prize:

“Computer games, films and large commercial ventures have a marketing budget that no newly published Nordic children's book can compete with. So the success of the prize will also depend on whether it becomes widely known. When the author Jacob Martin Strid was awarded the DKK 500,000 Kronprinsparrets Pris (Crown Prince Couple's Prize), the ceremony was broadcast live at prime time and received massive media coverage. It would be nice if the children's literature prize - and the other Nordic prizes - were given similar attention and followed as closely," she concludes.

\section{FACTS}

On 31 October 2013, the Nordic Council decided at its Session in Helsinki to set up a brand-new prize for children's and young people's literature. The prize will be awarded for the first time in 2013, and is independent of the prestigious Nordic Council Literature Prize.

The Nordic Council Children's and Young People's Literature Prize is worth DKK 350,000 and will be presented along with the awards for literature, music, film and the environment at the annual Session of the Nordic Council. 


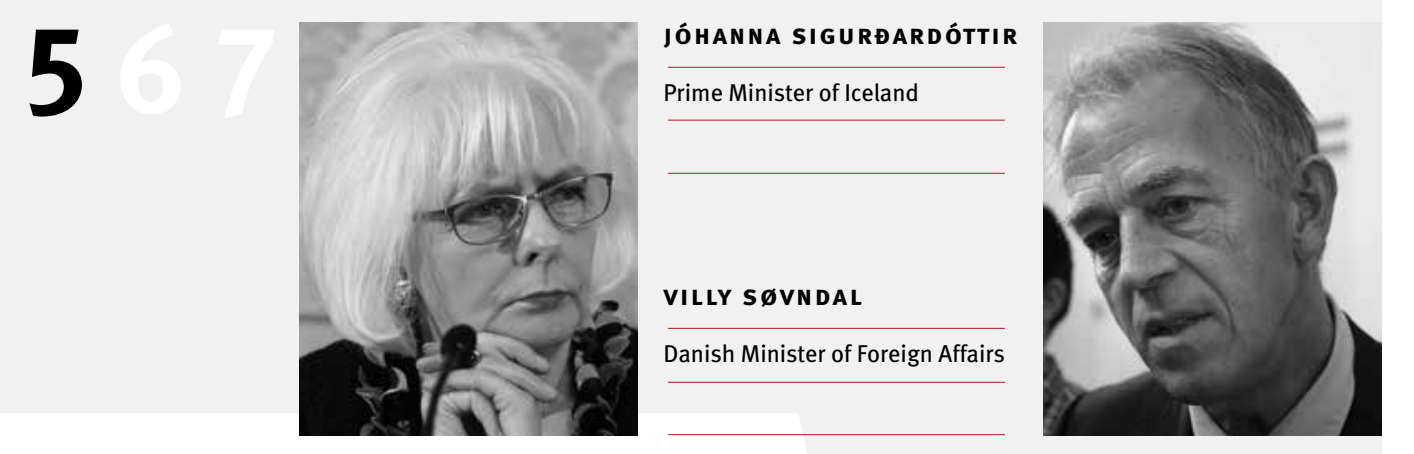

\section{External FORCES drive Nordic unity}

BY KARIN ARVIDSSON AND JESPER SCHOU-KNUDSEN

IT IS OFTEN CITED AS THE GREATEST FAILURE IN THE HISTORY OF NORDIC CO-OPERATION. NORDIC FOREIGN, DEFENCE AND SECURITY POLICY HAS NEVER HAD GREAT POLITICAL IMPACT. THE USSR AND THE USA PULLED THE NORDIC COUNTRIES IN DIFFERENT DIRECTIONS DURING THE COLD WAR, MAKING IT IMPOSSIBLE TO STICK TOGETHER.

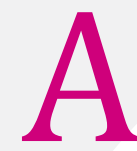

ll this has changed. Everybody is in the same boat now - quite literally sometimes. On a Norwegian fjord cruise in summer 2012, the prime ministers agreed that the Nordic countries have never worked so closely together on defence and security, and that efforts should now be redoubled. The outcome does not have to be open debates in the Nordic Council and Council of Ministers, as long as the political will exists and progress is made. Climate change, the closure of the American base in Iceland and financial constraints have made the impossible possible. The Nordic Region has more to gain than ever before by acting together at international level.

The Nordic countries have worked more closely together on foreign, security and defence policy in recent years, co-ordinating ambitions as well as actions. The issues may be outside the scope of official co-operation, but ministers and MPs have discussed them in great depth and several tangible initiatives have emerged.
Defence co-operation was stepped up in 2009 with the establishment of NORDEFCO, an umbrella organisation under which the national armed forces work on logistics, training, operations, international deployment, etc. Working together is the key for Nordic armed forces faced with challenges such as the heavy spending cuts imposed since the end of the Cold War.

\section{THE ARCTIC - A TOP PRIORITY}

Climate change has catapulted the Arctic to the top of the geopolitical agenda, and there is great potential in joint Nordic action to preserve unique natural habitats and to promote social and cultural development in the Arctic. The melting of the ice caps may also completely redraw the strategic military map.

Another example of external change that has led to a more integrated Region can be found on Iceland, one of the few nations in the world that has no armed forces and is therefore unable to patrol its own skies. Since the USA closed its mili- 


\section{5}

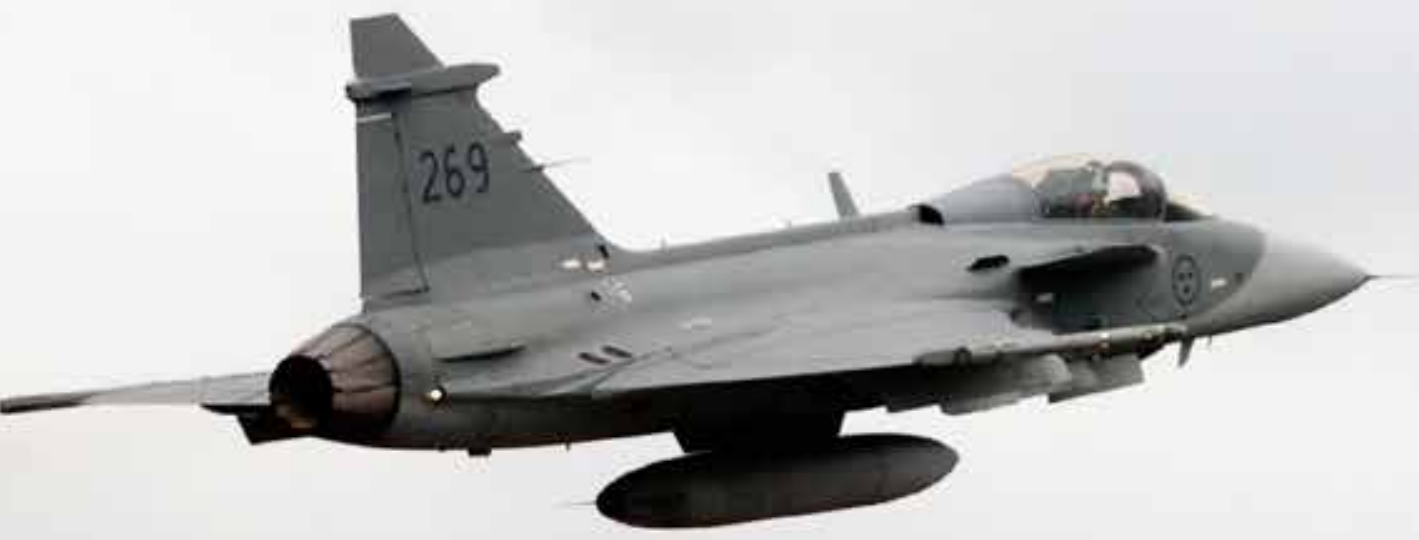

\section{FACTS}

The idea of the Nordic countries working closely together on defence issues has its roots all the way back in the 19th century. Intensive negotiations about a defence union collapsed just after World War II, partly because Denmark, Norway and Iceland opted to join NATO when it was set up in 1949. During the Cold War, there was little room for Nordic cooperation in the shadow of NATO and the Warsaw Pact. Commitment to working together has increased since the end of the Cold War. One milestone was the establishment in 2009 of the Nordic umbrella organisation NORDEFCO, under which the national armed forces work together in a wide range of areas such as logistics, training, operations and international deployment. In 2012, the prime ministers of Finland and Sweden declared that their countries will help Norway to provide air surveillance for Iceland from 2014. 
tary base in Keflavík in 2006, Norway has been providing air surveillance on a temporary basis. In October 2012, the Swedish and Finnish prime ministers agreed to lend a hand from 2014.

"Iceland really appreciates Nordic co-operation on foreign and security issues," says Prime Minister Jóhanna Sigurðardóttir. "I am delighted that the process has reached as far as joint air surveillance of Iceland - I also think it is a natural extension of Nordic co-operation."

\section{NEW DRIVING FORCES}

The Nordic Council has been working towards the next step in foreign and defence policy collaboration for some time, but Nordic ministers have been more reluctant.

"New superstructures are not what we need to join forces and strengthen the Region's role in the world," says the Danish Minister of Foreign Affairs, Villy Søvndal.

The main reasons for this are the effectiveness of the current arrangement and the fear that formalisation would complicate matters. History also casts long shadows, and even although the Cold War has ended, formalised defence co-operation could prove politically controversial.

One advocate of formalisation is Johan Strang of the Centre for Nordic Studies (CENS) in Helsinki, who discusses the issue in the Nordic Council's 2012 anniversary book, Nordic Communities, which forms part of the follow-up to the acclaimed Stoltenberg report (2009). Strang sees formalisation as a prerequisite for defence co-operation taking the next step. He argues that foreign and defence policy are now central to Nordic co-operation, and that this is because the driving forces behind co-operation have changed.

\section{EXTERNAL FORCES}

In his book, Strang writes: “When they were established in the 1950s and '70s, the official structures for Nordic co-operation were designed to provide a foundation for working together effectively within the Region. Today, however, the main focus is on the Region's relationships with the rest of the world."

"It is important that the Nordic countries are able to act as one in international bodies such as the EU, the UN and the Arctic Council. The lack of formal frameworks has made it difficult to draw up a common policy," he adds.

It remains to be seen whether the Region will opt for formalisation or not. What is clear, however, is that Nordic foreign, defence and security policy - for so long regarded as an anomaly - is now emerging from the shadows and beginning to take shape. This may involve many different types of work - joint defence, shared embassies, collective procurement, mutual solidarity and Nordic measures to fight climate change - as external forces drive Nordic unity. 

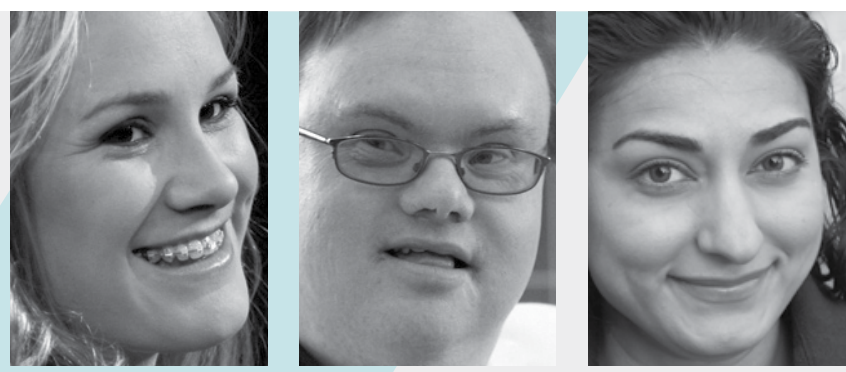

BIRGIT SKARSTEIN

MATS MELIN

Member of the Global

Known as Jerry, from the

Shapers Community,

a network of outstanding

food retailer ICA's

acclaimed commercials

young people
SHABANA REHMAN

Performance artist,

writer, debater, stand up

comedian

\section{No longer VICTIMS}

CROWDS FLOCKED TO THE NORDIC

BOOTHS AT THE 2012 BOOK FAIR IN

GOTHENBURG TO SEE AND HEAR THREE

CELEBRITIES. TWO HAVE DISABILITIES

AND ONE IS FROM AN IMMIGRANT

FAMILY - BUT THAT'S NOT WHY THEY

ARE CELEBRITIES. ats Melin was heartily sick of chopping wood - the only activity for disabled people provided by Hudiksvall Council in the north of Sweden - and perked up when his case worker, Pär Johansson, suggested to the council that theatre might be a better alternative. The Glada Hudik Theatre was formed, and the rest is history. After playing to full houses in its hometown, the troupe took its shows to Stockholm, to television and then to Broadway.

Hudik's next show is The Wizard of $\mathrm{Oz}$, in which Melin will be playing the dog, Toto. He has come a long way since he first tentatively trod the boards, and the whole of Sweden now knows him as Jerry, from the food retailer ICA's acclaimed commercials.

Mats describes himself as a "mega celebrity!" and readily admits to thriving in the spotlight.

Birgit Skarstein was 19 when an accident left her paralysed from the waist down. She is now a member of the Global Shapers Community, a network of outstanding young people established by the World Economic Forum. In other words, Birgit is considered to be one of the most influential figures in her part of the world. When she appeared on the Norwegian-Swedish TV show Skavlan, she talked about how she was studying political science in order to become a minister. "Why not Prime Minister?" the host wondered out loud. 


\section{7}
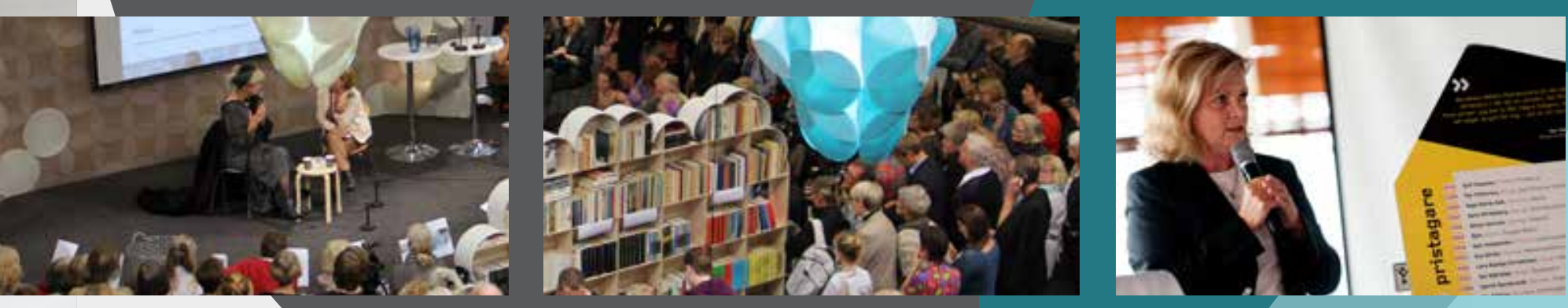

Skarstein first came to prominence on the TV programme Ingen Grenser ("Beyond Boundaries"), in which people with disabilities compete to make their way through a well-nigh impenetrable part of Africa.

"I didn't do it to become a celebrity," says Birgit. "It finally offered me a chance to appear on my own terms as a strong young person. No exhibition of disabilities, no victim role played out to tear-jerking music - simply a challenging task of getting from A to B."

Like many other girls of her generation, Shabana Rehman played Pippi or Ronia the Robber's Daughter when she was little.

“But I didn't look like the heroines in Nordic children's books. When I was born my complexion was so dark that even my Pakistani family were horrified and gave me the nickname Black Kali."

Shabana's grandma even cried at the thought of how difficult it would be to find her a husband. But as she grew up, her dad explained that the Hindu goddess Kali is beautiful, independent, loving and eloquent - traits Shabana shares.

"In Norway, we know her as a provocateur who focuses on integration and diversity issues, but who above all else is an outstanding performance artist, host and playwright," said Kjersti Stenseng, State Secretary of the Norwegian Ministry of Culture, when she introduced Shabana at the Gothenburg Book Fair.

In the 50 years since it was launched, the Nordic Council Literature Prize has helped to advance the careers of many successful and prominent writers. This was one reason why the Nordic Council and Council of Ministers wanted to focus on literature in Gothenburg, the largest book fair in the Region. But the ambition was greater than that. They also wanted to highlight the impor- 


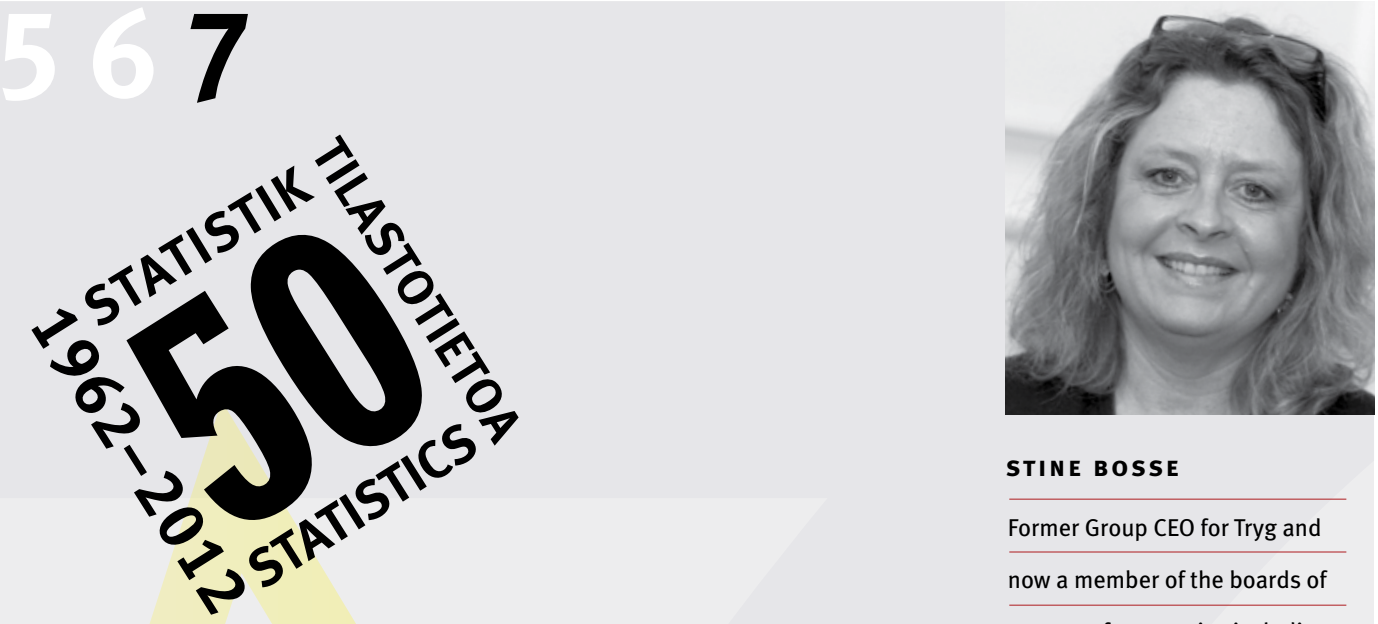

STINE BOSSE

Former Group CEO for Tryg and

now a member of the boards of

a range of companies including

Thought-provoking

Nordea and TDC DATA

BY LOUISE HAGEMANN

THE OCCASION WAS THE LAUNCH OF THE NORDIC STATISTICAL YEARBOOK 2012. AS STUDENTS VACATED THE ALEXANDER HALL AT THE UNIVERSITY OF COPENHAgEN, WE TOOK OUR PLACES IN THE FINE, OLD AUDITORIUM FOR A REVIEW OF HALF A CENTURY OF NORDIC STATISTICS, EAgER TO HEAR ABOUT THE GINI COEFFICIENT AND GDP. AFTERWARDS, WE DEPARTED WITH A MULTITUDE OF QUESTIONS IN OUR MINDS ABOUT THE KIND OF SOCIETY IN WHICH WE WANT OUR CHILDREN TO GROW UP.

$\mathrm{T}$ he figures speak for themselves. The Nordic countries have changed dramatically in the last 50 years, and our economy and welfare model now find themselves under massive pressure.

\section{THE TAX-GDP RATIO HAS INCREASED FROM 20-30\% IN THE EARLY 1960 S TO $36-48 \%$ TODAY}

Professor Christian Hjorth-Andersen centred his statistical retrospective around the big increase in taxes.

"When I was a student in the 1960s, there was a lively discussion about whether our social model would fall apart if the tax-GDP ratio exceeded $25 \%$ - that was the magic number," says the professor, noting with a smile that it has not happened.

Fortunately, society still functions. However, Stine Bosse, former Group CEO for Tryg and now a member of the boards of a range of companies including Nordea and TDC, is clearly concerned about developments - and even a little aggrieved. From 2003-2005, Stine sat on the Welfare Commission, which submitted a report to the Danish Government, clearly articulating that reform was imperative. She drily points out that the recommendation was dismissed as an erroneous and distorted view of the world.

"Had we taken these statistics seriously and opened our eyes to the trends that are exerting heavy pressure on the system now, we could have intervened sooner. We would have missed all the fun, of course, but it was frankly irresponsible," she stresses.

Then the financial crisis struck, and Denmark has had to introduce reforms to adapt the welfare model in its wake. Bosse is in absolutely no doubt that the model needs to be adjusted:

"When we look at these figures and trends, it's scary. But we mustn't start fearing that our model 


\section{7}

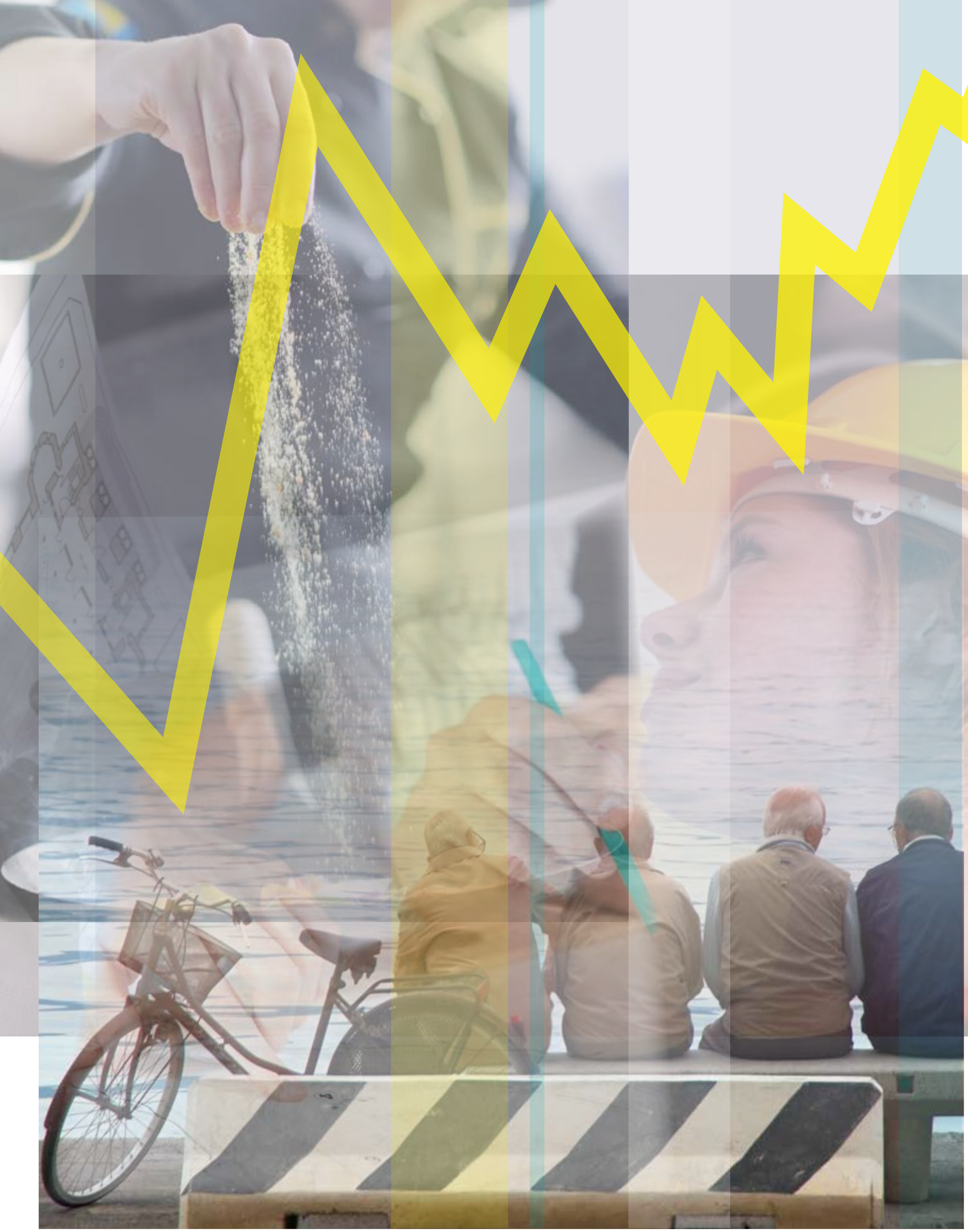


doesn't work. I'm absolutely convinced that the Nordic model, with its high degree of equality and social welfare, holds water."

\section{LIFE EXPECTANCY FOR NORDIC WOMEN \\ IS 83 COMPARED WITH 74 IN THE \\ EARLY 1960s}

Among the many thousands of figures in the Nordic Statistical Yearbook, the professor highlights perhaps the greatest threat to the welfare model:

"The population is significantly older now, which is a dramatic change common to all of the Nordic countries," Hjorth-Andersen says.

Bosse calls it "the good news" that we now live so much longer. But she also believes that we have to think in terms of a new division of responsibilities between the public and private sectors.

"As we live longer, we'll need knee and hip replacements. When the state is no longer able to sustain the rising costs of health care, we could set up a system of saving up for operations like that. But if you're out of work, then the state has to step in for a while so that everyone receives the help they need. We must make reforms and adopt new methods, while keeping a close eye on why it is so great to live in the Nordic Region compared to other countries," she says.

\section{IN 1960 THERE WERE 2 MILLION CARS IN THE NORDIC REGION; IN 2011 THERE WERE 12 MILLION - ALMOST ONE CAR FOR EVERY TWO PEOPLE}

For Bosse, who is also chair of Børnefonden (the Children's Fund) and the green think-tank CONCITO, the crisis is a temporary economic problem. She is far more concerned about developing a vision for the future that tackles climate change and the green transition head on. She points out that this will also involve respectful co-operation with Greenland in order to exploit the raw mineral resources there before the Chinese do.

"We have a huge obligation to give our children the prospect of a life that is better than ours," says Bosse. "African, Asian and South American youngsters are convinced that their lives will be better than their parents' and grandparents'. But we can't say to our kids that they should strive to have three cars or go on holiday four times a year. We have to give them something new - a new perspective and meaning to life. I don't know the answers, but the questions are clear enough."

Even though Sweden is coping best at the moment, all of the Nordic countries are "on top" in Europe, as Bosse puts it so appositely. Her clarion call to those of us in the Alexander Hall - and to the whole of the Nordic Region - is therefore that we have a special obligation to take the lead and come up with new visions for Europe.

\section{Nordic Statistical Yearbook}

Statistics have been collated and published in the Nordic countries since 1962 . They provide a unique insight into developments in the Region over the last 50 years. www.norden.org/tema/nordisk-statistik-i-50-aar
Stine Bosse LLB, born 1960.

Group CEO of TrygVesta A/S 2001-2011.

Chair of the board of Flügger Denmark, the Royal Theatre, CONCITO, Børnefonden, and Copenhagen Art Festival, and sits on the boards of, among others, Nordea Bank A/S, TDC, Allianz and Aker ASA.

In spring 2010, UN Secretary General Ban Ki-moon appointed Bosse to the Advocacy Group for the Millennium Development Goals, which aim to combat hunger and poverty. 

norden

Nordic Council of Ministers

Nordic Council

Ved Stranden 18

DK-1061 Copenhagen K

www.norden.org 